\title{
Low frequency of p53 mutations in cervical carcinomas among Brazilian women
}

N.A. Pinheiro ${ }^{1,2}$ and L.L. Villa ${ }^{2}$
${ }^{1}$ Departamento de Bioquímica, Instituto de Química, Universidade de São Paulo, São Paulo, SP, Brasil

${ }^{2}$ Instituto Ludwig de Pesquisa sobre o Câncer, São Paulo, SP, Brasil

\section{Correspondence \\ L.L. Villa \\ Instituto Ludwig de Pesquisa \\ sobre o Câncer \\ Rua Prof. Antonio Prudente, 109 \\ 4 을 an \\ 01509-010 São Paulo, SP \\ Brasil \\ Fax: + 55-11-270-7001 \\ E-mail: Ilvilla@node1.com.br \\ N.A. Pinheiro was the recipient of a fellowship from CNPq. Publication supported by FAPESP.}

Received August 21, 2000

Accepted April 2, 2001

\section{Abstract}

Human papillomavirus (HPV) infections of the high-risk types are strongly linked to the development of cervical carcinoma. The HPV oncoproteins E6 and E7 are thought to play a crucial role in this process through their interactions with the $\mathrm{p} 53$ protein and the retinoblastoma susceptibility gene product $\mathrm{pRb}$, respectively. E6 binds to p53 protein promoting its degradation. This is considered to contribute to the oncogenesis of HPV-associated anogenital cancer. On the other hand, in HPV-negative cervical carcinoma, p53 mutations are thought to have a role in the transformation process. A total of 122 HPV-positive cervical carcinoma tissue samples were evaluated for the presence of mutations in exons 5-8 of the p53 gene by singlestranded conformation polymorphism analysis and DNA sequencing. Only four missense point mutations were detected. These findings suggest that other mechanisms independent of p53 inactivation may play a role in the genesis of cervical carcinomas.

\section{Introduction}

Carcinoma of the uterine cervix is the third most frequent of the female genital malignancies. In recent years, human papillomavirus (HPV) has been identified as the etiological agent involved in the pathogenesis of this cancer $(1,2)$. Among more than 70 HPV types reported to date, types HPV 16 and 18 are the most prevalent and are found in more than $90 \%$ of primary cervical carcinomas in different geographic regions of the world $(3,4)$. These high-risk HPVs encode two transforming gene products, E6 and E7, whose proteins bind to $\mathrm{p} 53$ and $p R b$, respectively (5-7). The high-risk HPV E6 oncoprotein targets p53 degradation through a ubiq- uitin-dependent proteolysis system $(6,8) \cdot \mathrm{p} 53$ is also functionally inactivated by interaction with SV40 TAg, and E1B of adenovirus type 5 (Ad5E1B) (9).

The mechanisms by which these viral proteins inactivate p53 are distinct. In normal primary cells, the metabolic half-life of p53 is relatively short, between 20 and $40 \mathrm{~min}$ in most cell types. In SV40-immortalized cells, the steady-state level of $\mathrm{p} 53$ is elevated and the half-life is greatly extended (10). Ad5E1B has a similar effect on p53 stability and overall concentration. On the other hand, the level of p53 in HPV-containing cervical carcinoma cell lines and HPV-immortalized keratinocytes is generally lower than the level seen in primary cells and the half-life is decreased (6). 
The $\mathrm{p} 53$ protein is a nuclear phosphoprotein whose function is classified as a tumor suppressor (11) and has the properties of a transcriptional activator (12). The ability of p53 to bind to specific DNA sequences and to activate transcription indicates that this protein plays an important role in the regulation of cell proliferation. This gene is frequently mutated in nearly all types of human cancers (13). The majority of the studies involving the $\mathrm{p} 53$ gene examined only exons 5-8 in the central DNA-binding region, where the most commonly identified alterations of the p53 gene are single base pair substitutions $(13,14)$.

Several studies have examined the status of p53 in cervical carcinomas and recent data have suggested that it may have an important role $(12,15)$. Sequencing of p53 DNA from cervical carcinoma tissue and cell lines revealed wild-type p53 in HPVpositive tissues, whereas the mutated form was demonstrated only in HPV-negative tissues (15). Additional studies demonstrated that p53 mutations occur at higher frequencies in HPV-negative cervical carcinoma cell lines, but occur rarely in HPV-positive lines $(7,16)$. These findings led to the suggestion that inactivation of $\mathrm{p} 53$ function, either by mutation or by interaction with the HPV E6 gene product, is central to carcinogenesis in the cervix (17). The p53 mutants identified in HPV-positive anogenital cancers exhibit increased resistance to HPV E6-directed degradation, suggesting that mutation of $\mathrm{p} 53$ may play a role in the progression of HPVpositive cervical cancer (18).

To further understand the role of this tumor suppressor gene in HPV-associated neoplasia we performed an analysis of p53 gene alterations in a large series of cervical carcinomas from Brazil.

\section{Material and Methods}

\section{Samples, DNA extraction and HPV DNA typing}

Cervical carcinoma tissues were obtained during surgery from patients admitted to the Napoleão Laureano Hospital, João Pessoa, PB, Brazil, a high-risk area for this neoplasia. The institution's Ethics Committee approved the study and all patients gave their written consent. High molecular weight DNA was extracted from the tissue samples as previously described (19). Most of these tumors were classified histologically as squamous cell carcinomas. HPV DNA sequences were evaluated by both Southern blot analysis and PCR using generic primers MY09 and MY11, which amplify a 450-bp fragment of the L1 gene from the genital HPV types, followed by dot-blot hybridization and restriction fragment length polymorphism, allowing the detection of more than $40 \mathrm{HPV}$ types $(20,21)$.

\section{PCR-SSCP analysis of p53}

Genomic DNA isolated from HPV-negative and HPV-positive cervical carcinomas was amplified by PCR for each of exon 5, 6,7 and 8 so-called "hot spots" for p53 gene mutations. Single-stranded conformation polymorphism (SSCP) analysis of $\mathrm{p} 53$ mutations has been previously described (22-25).

The oligonucleotide primers employed flanked each exon and were obtained based on genomic sequences deposited in Genbank: for exon 5, sense: 5'-TACTCCCCTGCCCTC AACAAG-3' and antisense: 5'-CACCATCG CTATCTGAGCAGCG-3'; for exon 6, sense: 5'-CAGGGCTGGTTTCCCAGGGTCC CCA-3' and antisense: 5'-CAGGCGGCTCA TAGGGCA-3'; for exon 7, sense: 5'-GTGT TATCTCCTAGGTTGGC-3' and antisense: 5'-CAAGTGGCTCCTGACCTGGA-3'; for exon 8, sense: 5'-AGTGGTAATCTAC TGGGACGC-3' and antisense: 5'-TATC TCCATCCAGTGGTTTC-3'. These primer pairs for exons $5,6,7$ and 8 amplify products of $184,110,113$ and $137 \mathrm{bp}$, respectively.

DNA (200 ng) was subjected to PCR using nucleotides $\alpha^{\mathrm{P} 32}$-dCTP, deoxynucle- 
otide triphosphates $(0.2 \mathrm{mM}), 10 \mathrm{mM}$ Tris$\mathrm{HCl}, \mathrm{pH} 8.3,50 \mathrm{mM} \mathrm{KCl}, 1.5 \mathrm{mM} \mathrm{MgCl}_{2}$, 0.5 U Taq DNA polymerase (Cenbiot, Porto Alegre, RS, Brazil), $1 \mu \mathrm{M}$ of each primer, and the following cycling profile: for exons 5 and 8 , after heating for $5 \mathrm{~min}$ at $93^{\circ} \mathrm{C}, 35$ cycles of $5 \mathrm{~min}$ at $93^{\circ} \mathrm{C}, 30 \mathrm{~s}$ at $58^{\circ} \mathrm{C}$ and 2 min at $72^{\circ} \mathrm{C}$; for exons 6 and 7 heating for 5 min at $94^{\circ} \mathrm{C}$, and 32 cycles of $5 \mathrm{~min}$ at $94^{\circ} \mathrm{C}$, $1 \mathrm{~min}$ at $63^{\circ} \mathrm{C}$ and $7 \mathrm{~min}$ at $72^{\circ} \mathrm{C}$. A $4-\mu 1$ aliquot of the $\mathrm{PCR}$ products was diluted with a loading solution ( $95 \%$ formamide containing $0.05 \%$ xylene cyanol, $0.05 \%$ bromophenol blue and $20 \mathrm{mM}$ EDTA), denatured at $95^{\circ} \mathrm{C}$ for $10 \mathrm{~min}$ and then applied to $5 \%$ nondenaturing polyacrylamide gel containing either 5 or $10 \%$ glycerol. Electrophoresis was performed at 3 and 6 watts for the 5 and $10 \%$ glycerol gels, respectively. The gel was dried on filter paper and exposed to X-ray film at $37^{\circ} \mathrm{C}$ for $12 \mathrm{~h}$ with an intensifying screen.

We used DNAs extracted from the following tumors, previously shown to contain mutations in the p53 gene as positive controls: a gastric carcinoma with a $\mathrm{G} \rightarrow \mathrm{A}$ (codon 157) change in exon 5 , an HPV-negative penile carcinoma with an $\mathrm{A} \rightarrow \mathrm{G}(\operatorname{codon} 213)$ change in exon 6 , a penile carcinoma with two changes $(\mathrm{C} \rightarrow \mathrm{A}$ and $\mathrm{C} \rightarrow \mathrm{T}$ in codons 247 and 248, respectively) in exon 7 , and $\mathrm{C} 33$, an HPV-negative cervical carcinoma cell line that harbors a $\mathrm{C} \rightarrow \mathrm{T}$ change in codon 273 of exon 8 .

\section{p53 sequencing}

PCR-amplified DNA fragments with altered mobility as determined by SSCP-PCR analysis were cloned with the SureClone Ligation Kit (Pharmacia Biotech, Uppsala, Sweden) and the recombinant plasmids sequenced in an ALF Express ${ }^{\mathrm{TM}}$ DNA Sequencer (Pharmacia Biotech). Two different bacterial clones with the mutated or wildtype alleles were sequenced for each tumor sample.

\section{Results}

\section{Analysis of the p53 gene by SSCP-PCR}

HPV type distribution in these 122 cervical carcinomas was as follows: HPV 16 was the most prevalent type $(79 / 122,64.7 \%)$, followed by HPV 18 (6/122, 4.9\%), HPV 31 (1/122, 0.81\%), HPV 33 (2/122, 1.6\%), and HPV 45 (2/122, 1.6\%). We observed a high frequency of multiple infections: 11 tumors (9.0\%) contained HPV 16 and 18, and an even larger number of samples, $21 / 122$ (17.21\%), showed multiple infections with HPV 16 and other types.

DNA extracted from the tumors was subjected to PCR-mediated amplification of exons 5-8, which cover the coding region that encompasses most of the described mutations of the p53 gene. The amplified fragments for each exon were analyzed by SSCP. A representative example is shown in Figure 1. From this analysis, we inferred p53 mutations in only 4 out of the 122 tumors analyzed.

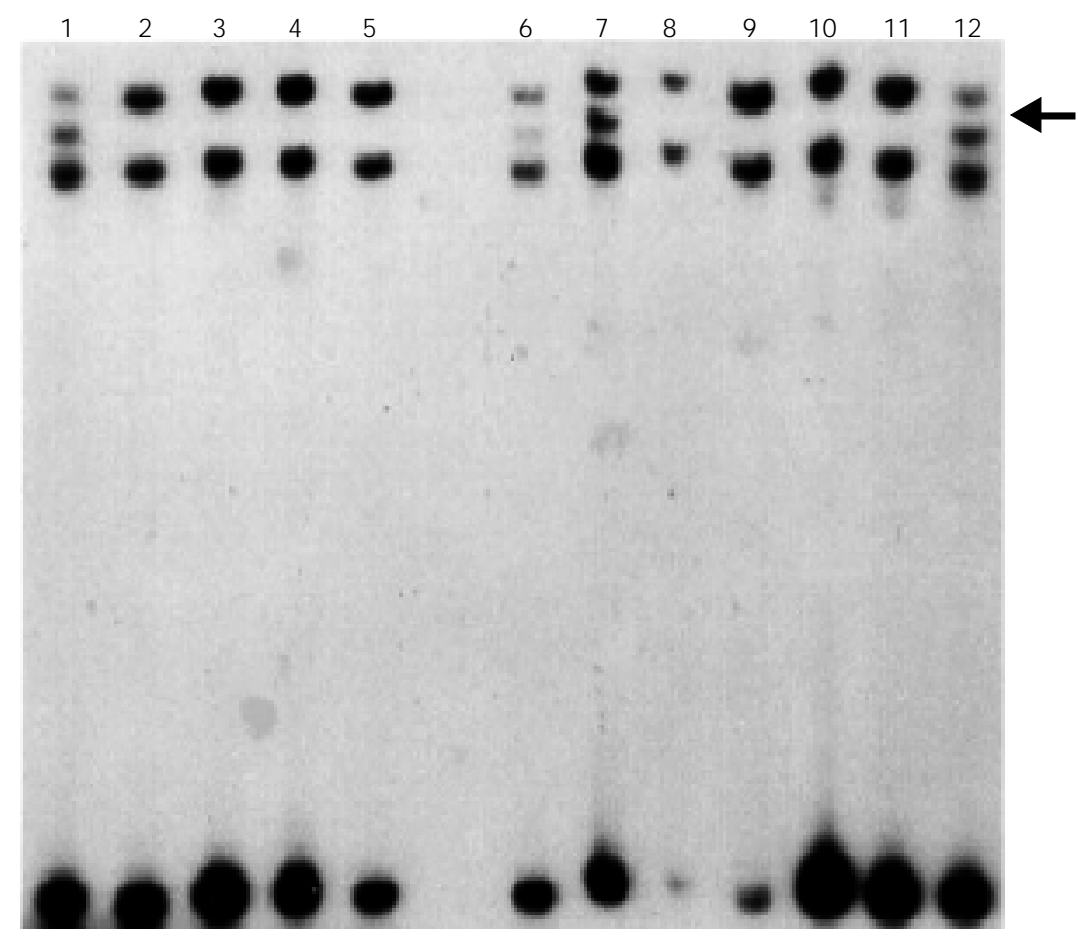

Figure 1. PCR-SSCP of p53 exon 6 in cervical carcinoma. Four samples present band shifts compatible with sequence alterations, as indicated by the arrow. 


\section{Sequencing of p53 gene exons 5-8}

Sequencing was performed on both the sense and antisense strands of the cloned exon 5, 6 and 8 fragments obtained from the HPV-positive cervical carcinomas. One specimen showed a single nucleotide change at codon 175 (GCG $\rightarrow$ GCA), which does not lead to amino acid substitution. On the other hand, two samples showed mutations at codon 213 (GAC $\rightarrow$ GGC), which results in an Asp to Gly change. Another nucleotide alteration was found in codon $277(\mathrm{ACA} \rightarrow \mathrm{A}$ AA), causing a Thr-Lys substitution.

\section{Discussion}

Almost all of human cervical carcinomas harbor HPV DNA sequences, and the viral E6 and E7 oncoproteins are generally expressed within these tumors (21). Evidence that the HPV E6 oncoprotein can bind p53 protein and promote its degradation suggests one mechanism by which the HPV viruses could mediate transformation $(26,27)$. The presence of an HPV sequence in a cell could represent the loss of the $\mathrm{p} 53$ function resulting from either a deletion or a mutation. If the abrogation of p53 function is really critical to cervical carcinogenesis, then either HPV infection or p53 gene mutation could fulfill this requirement. However, discrepancies are observed when comparing p53 data obtained from cell lines and clinical samples. It has been reported that HPVnegative cell lines contain $\mathrm{p} 53$ point mutations, whereas in HPV-positive cell lines, p53 is always of the wild type, suggesting that expression of E6 would mimic p53 mutations in the latter $(6,26,28)$. Data from several studies employing cervical carcinoma samples have failed to substantiate this, pointing to a small percentage of p53 mutations in this neoplasm, which occur irrespective of the HPV status of the tumor $(4,14$, 29,30).

Interaction of E6 from high-risk HPVs and mutant forms of $\mathrm{p} 53$ may be rare in vivo and complex to study in vitro. Some p53 mutants may present an E6-resistant phenotype, either by reduced affinity for E6, or by being less prone to proteolysis, and may accumulate even upon HPV 16 E6 expression. This apparent contradiction may be explained by E6 and mutated p53 not being present in the same cells, which is unlikely since it has been shown that E6 expression is required for progression of HPV-related tumors. Another explanation could be that E6 expression in vivo is not sufficient to eliminate the $\mathrm{p} 53$ protein or that in these tumors p53 complexes with cellular proteins hindering E6 access to it. These data indicate that E6-p53 interaction should not be considered the single mechanism of HPV-mediated transformation.

We have screened for p53 gene mutations $122 \mathrm{HPV}$-positive cervical carcinomas by SSCP analysis and DNA sequencing of exons 5-8, which have been reported to be the most common sites of mutations in this gene (13). Codon 213 was affected in 2 of the 4 p53-mutated samples, confirming this position as a "hot spot" in tumors from different anatomical sites (13). Of the 4 point mutations detected, 3 corresponded to missense mutations that may have implications for protein conformation. Moreover, these amino acid substitutions map to a region important for $\mathrm{p} 53$ DNA-binding activity, implying an eventual loss of function. However, functional studies are needed to confirm this implication. In fact, it was recently reported that cervical carcinoma cell lines containing transcriptionally active HPV display normal p53 transactivating function, including cell cycle arrest at $\mathrm{G}_{1}$ upon stimulation by genotoxic agents and irradiation.

Absences of 553 mutations in HPV-negative cervical tumors were reported by Helland et al. (31), who found no mutations in 6 HPV-negative patients. Similar results were reported by Choo et al. (32). Recently, these results were confirmed in larger series of 
cervical cancers. Kim et al. (33) showed that 2 out of $136(1.5 \%)$ tumors demonstrated SSCP band shifts. One sample (positive for HPV 18) had a nonsense mutation of codon 101 in exon 4 from AAA to TAA transversion. Another (HPV positive for the L1 consensus primer set) showed a point mutation involving codon 179 in exon 5 changing CAT to CGT transition. Three specimens negative for HPV did not contain p53 gene mutations. In another study 64 cases of primary cervix cancers were analyzed with a screening of the $\mathrm{p} 53$ gene mutations in exons 5 through 9 of this gene. SSCP analysis showed mobility shifts in 8 cases ( 6 in HPVpositive cases and 2 in HPV-negatives cases) and sequence analysis confirmed the results of SSCP (34).

Nakagawa et al. (35) analyzed mutation of the p53 gene in 45 women with cervical carcinomas. p53 mutations were analyzed by PCR-based SSCP and DNA sequencing techniques. Point mutation of the p53 gene was detected in 5 of $46(11 \%)$ cervical carcinomas, 1 of $17(8 \%)$ samples associated with high-risk HPVs (HPV 16 and HPV 18), and 4 of 27 samples (15\%) with intermediate risk HPVs, whereas no mutation was found in 2 HPV-negative cases.

Levi et al. (36) analyzed the presence of HPV DNA in a series of 84 paraffin-embedded penile carcinomas. They also investigated the presence of $\mathrm{p} 53$ mutations in these tumors by immunohistochemistry, SSCP and DNA sequencing. These data indicate that subsets of penile carcinomas are etiologically related to HPV and that an overlapping subset may rise from mutational events in the $\mathrm{p} 53$ gene.

The p53 gene regions examined in the present study represent only a fraction of this gene. However, the vast majority of known mutations identified in different primary tumors and cell lines clustered between amino acid residues 130 and 290 (11). This is a region where the DNA sequence is highly conserved among several different species (37). Although the frequency and distribution of these muta- tions may differ among cancers from different tissue types, p53 mutations in cervical carcinoma are localized within this region (38). Therefore, it is relatively safe to assume that we probably would have detected some $\mathrm{p} 53$ mutations within exons 5-8. However, one cannot exclude that some mutations are located outside the regions of the p53 gene examined by us and others $(14,32,39,40)$. Kurvinen et al. (40) determined the state of the p53 gene in 20 genital precancer lesions and carcinomas. Exons 5-9 of the p53 gene were analyzed by SSCP-PCR, and no mutations were detected in any of the specimens, including the $3 \mathrm{HPV}$-negative cases.

Coexistence of HPV DNA and a mutated form of p53 may suggest that these cells were mutated at the p53 locus and then became infected with HPV. Alternatively, the infection was an initial event and a point mutation on the p53 gene provided an additional growth advantage to the cells. In fact, Crook et al. (41) indicated that mutations within the p53 gene in an HPV-positive primary cancer might confer a growth advantage and contribute to the acquisition of metastatic potential in these cells.

The present results may account to the existence of other tumor suppressor genes whose inactivation or loss of function is important for cervical carcinogenesis. This is compatible with the fact that the frequency of $\mathrm{p} 53$ mutation reported in these tumors is low when compared with other cancers. Our results confirm that the occurrence of somatic mutations in the hot spot region of the p53 gene is indeed very low in HPV-positive cervical carcinoma.

\section{Acknowledgments}

We acknowledge the Medical staff of the Napoleão Laureano Hospital, João Pessoa, $\mathrm{PB}$, Brazil, for providing the tumor samples, and Anaésia Silva for sample handling. We are grateful to Antonio L. Ruiz for technical assistance in HPV detection and typing. 


\section{References}

1. Villa LL (1997). Papillomaviruses and cervical cancer. Advances in Cancer Research, 71: 321-341.

2. Zur Hausen H (1996). Papillomavirus infections - a major cause of human cancers. Biochimica et Biophysica Acta, 1288: F55-F78.

3. Bosch FX, Manos MM, Muñoz N, Sherman $M$, J ansen $A M$, Peto J, Schiffman $\mathrm{MH}$, Moreno V, Kurman R, Shah KV \& International Biological Study on Cervical Cancer (IBSCC) Study Group (1995). Prevalence of human papillomavirus in cervical cancer: a worldwide perspective. J ournal of the National Cancer Institute, 87: 796-802.

4. Borresen AL, Helland A, Nesland J, Holm R, Trope C \& Kaern J (1992). Papillomaviruses, p53, and cervical cancer. Lancet, 339: 1350-1351.

5. Dyson N, Howley PM, Münger $K \&$ Harlow E (1989). The human papillomavirus-16 E7 oncoprotein is able to bind to the retinoblastoma gene product. Science, 243: 934-937.

6. Scheffner $M$, Munger $K$, Byrne J $C \&$ Howley PM (1991). The state of the p53 and retinoblastoma genes in human cervical carcinoma cell lines. Proceedings of the National Academy of Sciences, USA, 88: 5523-5527.

7. Wrede D, Tidy J A, Crook T, Lane D \& Vousden KH (1994). Expression of RB and p53 proteins in HPV-positive and HPVnegative cervical carcinoma cell lines. Molecular Carcinogenesis, 4: 171-175.

8. Huibregtse J M, Scheffner $M \&$ Howley PM (1994). E6-AP directs the HPV E6dependent inactivation of p53 and is representative of a family of structurally and functionally related proteins. Cold Spring Harbor Symposia on Quantitative Biology, LIX: 237-245.

9. Lane DP \& Crawford LV (1979). T antigen is bound to a host protein in SV40-transformed cells. Nature, 278: 261-263.

10. Reich NC, Oren M \& Levine AJ (1983). Two mechanisms regulate the levels of a cellular tumor antigen, p53. Molecular and Cellular Biology, 3: 2143-2150.

11. Levine AJ , Momand \& \& Finlay CA (1991). The $p 53$ tumour suppressor gene. Nature, 351: 453-456.

12. Funk WD, Pak DT, Karas RH, Wright WE \& Shay J W (1992). Transcriptionally active DNA-binding site for human p53 protein complexes. Molecular and Cellular Biology, 12: 2866-2871.
13. Hollstein $M$, Sidransky D, Vogelstein B \& Harris CC (1991). p53 mutations in human cancers. Science, 253: 49-53.

14. Busby-Earle RMC, Steel CM, Williams ARW, Cohen B \& Bird CC (1992). Papillomaviruses, p53 and cervical carcinoma. Lancet, 339: 1350.

15. Crook T, Wrede D \& Vousden KH (1991). p53 point mutation in HPV negative human cenvical carcinoma cell lines. Oncogene, 6: 873-875.

16. Srivastava $S$, Tong $Y A$, Devadas $K$, Zou ZQ, Chen Y, Pirollo KF \& Chang EH (1992). The status of the p53 gene in human papilloma virus positive or negative cervical carcinoma cell lines. Carcinogenesis, 13: 1273-1275.

17. Park DJ, Wilczynski SP, Paquette RL, Miller CW \& Koeffler HP (1994). p53 mutations in HPV-negative cervical carcinoma. Oncogene, 9: 205-210.

18. Crook T \& Vousden KH (1992). Properties of p53 mutations detected in primary and secondary cervical cancers suggest mechanisms of metastasis and involvement of environmental carcinogens. EMBO J ournal, 11: 3935-3940.

19. Krieg $P$, Antmann $E \&$ Sauer $G$ (1983). The simultaneous extraction of high molecular weight DNA and of RNA from solid tumours. Analytical Biochemistry, 134: 288-294.

20. Bauer HM, Yi Ting MS, Chambers J C, Tashiro CJ, Chimera J, Reingold A \& Manos MM (1991). Genital human papillomavirus infection in female university students as determined by PCR-based methods. J ournal of the American Medical Association, 265: 23-30.

21. Walboomers J M, Jacobs MV, Manos $M M$, Bosch FX, Kummer JA, Shah KV, Snijders PJ , Peto J , Meijer CJ \& Munoz N (1999). Human papillomavirus is a necessary cause of invasive cervical cancer worldwide. J ournal of Pathology, 189: 1219.

22. Hayashi $K$, Orita $M$, Suzuki $Y \&$ Sekiya $T$ (1989). Use of labeled primers in polymerase chain reaction (LP-PCR) for a rapid detection of the product. Nucleic Acids Research, 17: 3605.

23. Kishimoto $Y$, Murakami $Y$, Shiraishi $M$, Hayashi K \& Sekiya T (1992). Aberrations of the p53 tumor suppressor gene in human non-small cell carcinomas of the lung. Cancer Research, 52: 4799-4804.

24. Murakami Y, Hayashi K \& Sekiya T (1991). Detection of aberrations of the p53 alleles and the gene transcript in human tumor cell lines by single-strand conformation polymorphism analysis. Cancer Research, 51: 3356-3361.

25. Orita M, Iwahana $H$, Kanazawa $H$, Hayashi K \& Sekiya T (1989). Detection of polymorphisms of human DNA by gel electrophoresis as single-strand conformation polymorphisms. Proceedings of the $\mathrm{Na}$ tional Academy of Sciences, USA, 86: 2766-2770.

26. Scheffner $M$, Werness BA, Huibregtse J M, Levine AJ \& Howley PM (1990). The E6 oncoprotein encoded by human papillomavirus types 16 and 18 promotes the degradation of p53. Cell, 63: 1129-1136.

27. Werness BA, Levine AJ \& Howley PM (1990). Association of human papillomavirus types 16 and 18. Science, 248: 76-79.

28. Liang XH, Volkman M, Klein R, Herman $B$ \& Lockett SJ (1993). Co-localization of the tumor-suppressor protein p53 and human papillomavirus E6 protein in human cervical carcinoma cell lines. Oncogene, 8: 2645-2652.

29. Busby-Earle RM, Steel $C M$, Williams $A R$, Cohen B \& Bird CC (1994). p53 mutations in cervical carcinogenesis - low frequency and lack of correlation with human papillomavirus status. British J ournal of Cancer, 69: 732-737.

30. Kong G, Choo B \& Chong KY (1993). Absence of mutation in the p53 and the retinoblastoma susceptibility genes in primary cervical carcinomas. Virology, 193: 1042-1046.

31. Helland A, Holm R, Kristensen G, Kaem J , Karesen F, Trope C, Nesland J M \& B prresen A-L (1993). Genetic alterations of the TP53 gene, p53 protein expression and HPV infection in primary cervical carcinomas. J ournal of Pathology, 171: 105114.

32. Choo KB, Chong KY, Liew L-N \& Hsu Cheng W (1993). Unregulated and basal transcriptional activities of the regulatory sequence of the type 18 human papillomavirus genome in transgenic mice. J ournal of Virology, 188: 378-383.

33. Kim J W, Cho YH, Lee CG, Kim J H, Kim HK, Kin EJ, Ham KT \& Namkoong SE (1997). Human papillomavirus infection and TP53 gene mutation in primary cervical carcinoma. Acta Oncologica, 36: 295300.

34. Kim KH \& Kim YS (1995). Role of human papillomavirus and p53 tumor suppressor gene in cervical carcinogenesis. Yonsei 
Medical J ournal, 36: 412-425.

35. Nakagawa S, Yoshikawa $\mathrm{H}$, J imbo $\mathrm{H}$, Onda T, Yasugi T, Matsumoto K, Kino N, Kawana K, Kozuka T, Nakagawa K, Aoki M \& Taketani Y (1999). Elderly J apanese women with cervical carcinoma show higher proportions of both intermediaterisk human papillomavirus types and p53 mutations. British J ournal of Cancer, 79: 1139-1144.

36. Levi JE, Rahal P, Sarkis AS \& Villa LL (1998). Human papillomavirus DNA and p53 status in penile carcinomas. International J ournal of Cancer, 76: 779-783.
37. Soussi $T$, Caron de Fromentel $C \&$ May $P$ (1990). Structural aspects of the p53 protein in relation to gene evolution. Oncogene, 5: 945-952.

38. Pao CC, Kao SM, Tang GC, Lee KSIJ \& Ruan S (1993). Human papillomavirus and cervical carcinoma in China and Taiwan. Lancet, 342: 937.

39. Chen TM, Chen CA, Hsieh Cy, Chang Dy, Chen Yh \& Defendi V (1992). The state of p53 in primary human cervical carcinomas and its effects in human papillomavirusimmortalized human cervical cells. Oncogene, 8: 1511-1518.
40. Kurvinen K, Tervahauta A, Syrjanen S, Chang F \& Syrjanen K (1994). The state of the p53 gene in human papillomavirus (HPV)-positive and HPV-negative genital precancer lesions and carcinomas as determined by single-strand conformation polymorphism analysis and sequencing. Anticancer Research, 14: 177-181.

41. Crook T, Wrede D, Tidy J A, Mason WP, Evans DJ \& Vousden KH (1992). Clonal p53 mutation in primary cervical cancer: association with human-papillomavirusnegative tumors. Lancet, 339: 1070-1073. 